DOl: $10.19195 / 2353-8546.8 .14$

\author{
TOMASZ NAKONECZNY* \\ Uniwersytet im. A. Mickiewicza (Poznań, Polska) \\ ORCID: 0000-0002-4241-7862
}

\title{
W poszukiwaniu utraconego imperium. Polska imperialna jako świat i jako wyobrażenie
}

\begin{abstract}
In searching for a lost empire. Imperial Poland as a world and an idea. The heritage of the PolishLithuanian Commonwealth is one of the most problematic residues of the Polish past. After World War II, Poland lost its so-called Eastern Borderlands, which meant a break with a specific state tradition, the most important link of which was the powerful Polish-Lithuanian state in the fifteenth and sixteenth centuries. The potential and significance of the former Polish-Lithuanian Commonwealth remains an important topic of Polish identity discourse. One of the issues addressed in that context is the imperial character of that state. The importance of this issue goes beyond the space of historiographic debates. It also concerns the place and role of Poland in the world from both historical and contemporary perspective. A common element of various narratives around the national-state status is myth. Myth is a story told for the needs of a specific social group, but it also refers to some of the supra-class conditions that could be described as the ontology of national being. Thanks to this, it can be treated as one of the tools used to study not only self-perceptions of the community, but also the interactions that occur between these self-images and real determinants of the community's status. According to the author of the article, postcolonial studies create a possibility of integrated research on Polish imperiality, since they combine a number of different competencies necessary to comprehensively cover this broad topic. The sphere of national mythology is combined from a postcolonial perspective with a vast sphere of social facts and real-life conditions.
\end{abstract}

Keywords: imperialism, postcolonial studies, myth, the Polish-Lithuanian Commonwealth, national-state status

* Adres do korespondencji: Instytut Wschodni Uniwersytetu im. Adama Mickiewicza w Poznaniu, ul. Umultowska 89 D, 61-614 Poznań. E-mail: tomasz.nakoneczny@wp.pl. 
Wyrażenie „polski imperializm” skazane jest w dzisiejszym uzusie językowym na egzystencję wielce umowną, cudzysłowową: $w$ odniesieniu do pewnych aspektów bieżącej polityki używa się go najczęściej w charakterze oksymoronu i niemal wyłącznie w trybie ironicznym, traktując jako symptom utopijno-fantasmagorycznych aspiracji do odgrywania w sferze stosunków międzynarodowych roli, do jakiej nie uprawnia Polaków ani potencjał ich kraju, ani kwalifikacje ich kadr przywódczych. Przychylniejsza dla niego semantyka towarzyszy zwykle próbom implementacji do współczesnej kultury artystycznej bądź do współczesnego dyskursu ideologicznego (neosarmatyzm) niektórych, często selektywnie dobranych i jawnie przetworzonych, elementów dawnej mitologii szlacheckiej („Polska od morza do morza”, „Przedmurze chrześcijaństwa” itp.).

Urealniającego znaczenia nabiera „polski imperializm” dopiero za sprawą określonej rekontekstualizacji, historiograficznej bądź kulturalistycznej: w obszarze refleksji nad dziejami Rzeczypospolitej Obojga Narodów oraz nad długofalowymi następstwami jej upadku. Klasyczne już dzisiaj spory o to, czy i w jakim stopniu charakterystyka państwa polsko-litewsko-ruskiego odpowiada przyjmowanym w nauce definicjom imperializmu, wpisano niemal w całości do domeny dyskursu historiograficznego i w tej mierze zdają się one angażować głównie zawodowych historyków. Wszelako pojawiają się na marginesie tych sporów, a od pewnego czasu niezależnie od nich, próby dalej idących uogólnień na temat imperialnych aspektów już nie samej tylko formacji państwowo-ustrojowej I Rzeczypospolitej, lecz także polskiej kultury i tożsamości w perspektywie ich długiego trwania/ewolucji. Co więcej, wątki „imperialne” pojawiają się również w analizach bieżącej polityki państwa polskiego, co z pewnością zasługiwałoby na odrębne studium ${ }^{1}$.

Wydawałoby się, że zagadnienie polskiego imperializmu, odczytywanego zarówno w kategoriach kulturalistycznych, jak ekonomicznych i społecznych, powinno spotkać się ze szczególnie szerokim i wnikliwym zainteresowaniem na gruncie rodzimych studiów postkolonialnych. Tak jednak jest w ograniczonym tylko

${ }^{1} \mathrm{~W}$ analizach tego rodzaju polska polityka ukazywana bywa w perspektywie rywalizacji z Rosją, co już samo w sobie nawiązuje do historycznych konfliktów ze wschodnim mocarstwem i do ich geopolitycznego podłoża. Konfliktów zatem motywowanych potrzebą dominacji nad określonym, wyznaczonym geopolityczną logiką, obszarem. Określenia „imperium”, „imperialny” odnoszące się do Polski są przytaczane w podobnych razach w trybie cudzysłowowym, co jednak nie powinno przesłaniać wymiaru implicytnego, o jakim mowa. „Rosyjskie dążenie do wyeliminowania zależności od tranzytu gazu przez Polskę i Ukrainę sięga roku 2000, kiedy to w Paryżu miał miejsce unijny szczyt z Rosją. Wspólna strategia ominięcia Polski jest odpowiedzią na wejście RP do Sojuszu Północnoatlantyckiego i jednoznaczne opowiedzenie się Polski po stronie koncepcji rozciągnięcia strefy amerykańskich wpływów na kraje postradzieckie. Polska od kilku lat prowadzi politykę blokowania rosyjskich inwestycji w Europie Środkowej i podjęła wysiłek utworzenia polskiego „imperium” energetycznego, czego symbolicznym wyrazem było zorganizowanie (jedynego, jak dotąd) szczytu energetycznego z udziałem Litwy, Azerbejdżanu, Gruzji i Ukrainy w Krakowie w 2007 roku”, R. Borkowski, „Bezpieczeństwo strategiczne RP w kontekście amerykańskiej polityki wobec Europy Środkowej i konfliktu ukraińskiego”, [w:] Dylematy polityki bezpieczeństwa Polski na początku drugiej dekady XXI wieku, red. K. Czornik, M. Łakomy, Katowice 2014, s. 131. 
zakresie, znacznie, jak sądzę, węższym, niż wynikałoby to $\mathrm{z}$ wagi zagadnienia oraz z jego dyskursywnego potencjału.

Dzieje się tak po części dlatego, że zagadnienie polskiego imperializmu poddawane było dotąd fragmentarycznemu i - przede wszystkim — zbyt jednostronnemu oglądowi. Brakowało dla niego płaszczyzny dyskusji uwzględniającej punkty widzenia inne niż stricte historiograficzne oraz wrażliwości ukształtowanej przez narracje inne niż romantyczno-narodowe. Rozciągnięte między debatami historyków nad prawomocnością — w świetle dostępnych źródeł — samego terminu „polski imperializm" (a więc przypisywane do określonych ram czasoprzestrzennych i społeczno-politycznych) a „radosną twórczością” kulturalistów, skorych raczej do czynienia z niego samorodnego, niejako ponadhistorycznego komponentu polskiej świadomości (zatem będące przedmiotem swoistej multiplikacji polegającej na przydawaniu mu wciąż nowych odcieni znaczeniowych), zdaje się z jednej strony zatracać kontury i proporcje, jakie wyznacza semantyka źródłowego dla niego pojęcia imperium, z drugiej zaś ulegać nadmiernej ideologizacji, której wyrazistymi symptomami są całkowita dyskredytacja odwołująca się do dzisiejszej liberalnej aksjologii bądź romantyczna idealizacja odwołująca się do ukształtowanych przez minione pokolenia wyobrażeń dawnej potęgi i chwały ${ }^{2}$.

Myślę, że wyodrębniająca się w Polsce od kilku dekad przestrzeń debaty postkolonialnej może być dogodnym forum do dyskusji nad polskim syndromem imperialnym. Najważniejszą zaletą polskich postcolonial studies jest w tym wypadku ich otwarta, mimo inklinacji „literaturocentrycznych”, kulturalistyczna orientacja, co w połączeniu $\mathrm{z}$ brakiem terminologicznej petryfikacji sprzyja promowanej w ramach tego nurtu badań multiperspektywiczności/interdyscyplinarności. Multiperspektywiczność oznaczałaby tu możliwość powiększenia pola dyskusji wokół problematyki imperialnej w kontekście polskim. Zagadnienie „polskiego imperializmu” sytuuje się wszak na przecięciu różnych szlaków dyskursywnych i imagologicznych. Dotyczy zarówno pytań natury metodologiczno-warsztatowych, jak i gotowych tekstualnych wytworów: potocznych wyobrażeń zaklętych w stereotypie Polski „od morza do morza", romantyczno-literackich idealizacji polskości oraz polskiej misji cywilizacyjnej na Kresach czy też politycznych tudzież historiozoficznych konceptualizacji polskiej podmiotowości i wynikających z nich dyrektyw prakseologicznych.

Mianem polskiego syndromu imperialnego określam złożone i trudno w istocie uchwytne zjawisko uobecniania się mitu polskiej potęgi, świetności i chwały, związane genetycznie z historycznym statusem I Rzeczypospolitej. Nie da się ukryć, że estyma w stosunku do tak czy inaczej rozumianej „wielkiej przeszłości” Polski

2 „Tak się składa, że czuć się spadkobiercami imperium Polacy mogą jedynie w Europie Wschodniej, gdzie polska kultura kiedyś dominowała, wyznaczała trendy i stanowiła o wyższym poziomie cywilizacyjnym. Była, innymi słowy, atrakcyjniejsza. Europa Wschodnia to jedyny region świata, w którym polski paszport, zwłaszcza że teraz też unijny, robi jeszcze wrażenie, a jego właściciel uchodzi za przybysza z lepszego świata", A. Brzeziecki, Imperialne złudzenia Polski, 2017, https://www.reddit.com/r/ Polska/comments/6cnj0j/imperialne_z\%C5\%82udzenia_polski/ (dostęp: 6.09.2018). 
stosunkowo rzadko podlega dziś otwartej artykulacji; funkcjonuje co najwyżej jako ukryta presupozycja kulturowa. Trudno tu zresztą mówić o jednym micie jako takim. Mamy raczej do czynienia z sekwencją powiązanych wzajem, niekiedy dość luźno, artefaktów mitycznych (narracji, postaci, zdarzeń, symboli), przywoływanych przy różnych okazjach i na różne sposoby (uroczysta celebracja rocznicy wiktorii wiedeńskiej w 1983 roku, obchodzone corocznie rocznice grunwaldzkie, ekranizacje kolejnych części Trylogii, działania grup rekonstrukcyjnych itp.; listę tę można by znacząco wydłużyć). Na pierwszy rzut oka mogłoby się wydawać, że waga, jaką mają dla współczesnej polskiej tożsamości remityzowane obrazy minionej chwały, jest wprost proporcjonalna do ich właściwości kompensacyjnych. Mit państwa wielkiego, zdolnego do narzucania swojej woli innym, słabiej uposażonym narodom, powinien przemawiać do wyobraźni narodu doświadczającego od kilku pokoleń traum i porażek swoją mocą już to mobilizującą, już to konsolacyjną. Ale tak przecież nie jest. Albo jest, ale w nader ograniczonym stopniu. Mity auto- i metasarmackie są wyraźnie przesłonięte mitami późniejszymi, na przykład powstańczymi. Dlatego uważam, że znaczenie tych pierwszych polega na czym innym. Ich podstawowy walor w kontekście polskiego dyskursu tożsamościowego nie wyraża się w funkcji terapeutycznej, lecz poznawczej: polskie mity imperialne wpisują się bowiem w pewne ogólne wzorce funkcjonowania polskiej wspólnoty jako takiej, tworzą ogniwa pojemniejszych struktur kognitywnych związanych z fundamentalnymi, realnobytowymi wyznacznikami narodowego losu.

Przeskok od „zagadnienia” do „mitu” mógłby sugerować, że mamy tu do czynienia $\mathrm{z}$ dwiema zupełnie różnymi formami tematyzacji tego samego fenomenu „badawczą" i „kulturową” - gdy tymczasem są to jedynie różne jego słownikowe ujęcia związane z różnymi poziomami jego „kulturalizacji”. Nie powinniśmy zapominać, że adaptacja danego pojęcia na gruncie dyskursu naukowego nie czyni mniej „kulturowym” ani samego pojęcia, ani tym bardziej dyskursu. Zagadnienie "polskiego imperializmu” $i$ „mit polskiego imperializmu” to jakby dwa - odwołując się do metaforyki muzycznej - przetworzenia tematu. Czym zaś jest ów „temat”, można wyrazić następująco: jest nim to, co składa się na realną, pozadyskursywną, egzystencję Polski rozumianej jako byt zajmujący określoną przestrzeń, wyposażony w określoną moc działania, wchodzący w określonego rodzaju interakcje z innymi, podobnymi bytami wspólnotowymi itp.

Czynnikiem scalającym struktury wyobrażeniowe spod znaku imperialności pozostaje ich ciążenie ku mityzacji. Warto zauważyć, że mit i mityzacja nie są zjawiskami dającymi się przypisać do jednego słownika (na przykład etnologicznego, językoznawczego czy historycznego): zbyt duże tu nagromadzenie heterogeniczności. Mit powstaje co prawda w łonie określonej wspólnoty językowej, idiosynkratycznej i lokalnej, lecz będąc jednocześnie historią odwołującą się do pewnej uniwersalnej gramatyki, oddziela się od swojej podstawy i uzyskuje zdolność do samoistnego bytu kulturowego. Prześledzenie etapów powstawania i „dojrzewania” mitu wymagałoby integracji bardzo różnych kompetencji badawczych; na nasze potrzeby wystarczy 
stwierdzenie możliwości wyodrębnienia w micie jego historycznego substratu (mit jako sui generis analogon rzeczywistości). Zaproponowana przeze mnie wykładnia nawiązuje świadomie do semiotyczno-strukturalistycznej poetyki mitu. Jak zauważa jeden z głównych przedstawicieli tej orientacji, Claude Lévi-Strauss:

mit zachowuje wartość mitu nawet przy najgorszym tłumaczeniu. Nawet jeśli znajomość języka i kultury ludu, wśród którego znaleziono jakiś mit, jest znikoma, jest on pojmowany jako mit przez każdego czytelnika na świecie. Substancja mitu nie tkwi ani w stylu, ani w sposobie narracji, ani w składni, lecz w historii którą się tam opowiada. Mit jest mową, ale jest to mowa, która porusza się na bardzo wysokim poziomie i gdzie znaczenie odrywa się, jeśli wolno tak powiedzieć, od podstawy językowej, po której początkowo się toczy ${ }^{3}$.

Semiotyczno-strukturalistyczna perspektywa, w jakiej osadzam swoją wykładnię mitu (jako historii zarazem lokalnej i uniwersalnej), nie powinna skupiać na sobie naszej uwagi. Istotne jest to, że podsuwa ona pewien pomysł na uporanie się z pozorną wieloznacznością pojęcia mitu: przypominając, że jest on określoną fabułą (mythos) podlegającą określonemu wysłowieniu (lexis), zachęca do patrzenia nań jako na strukturę zawierającą pewien szyfr bądź - jak się utarło w języku potocznym pewne przesłanie. Możliwość poszukiwania w każdym micie narodowym owego szyfru-przesłania, immanentnej logiki łączącej go z „obiektywnymi” danymi rzeczywistości - historią, geopolityką, charakterem narodowym itp., sprawia, że nader często mamy tu do czynienia ze strukturami wykazującymi się znaczną żywotnością. Powtarzające się w różnych wysłowieniach aktualizacje mitu narodowego przemawiają za tym, by widzieć w nim narzędzie rozpoznawania pewnych obiektywnych zależności; w przypadku interesującego nas tu zagadnienie polskiego imperializmu, chodziłoby o zależności związane ze statusem narodu i jego państwa, a więc zależności wpisujące się na gruncie badań postkolonialnych w matrycę centro-peryferyjności.

Przykładem mitu odznaczającego się taką właśnie żywotnością może być, odnawiany przy okazji kolejnych rocznic oraz mniej czy bardziej okrągłych jubileuszy, mit grunwaldzki (wpisujący się w pojemniejszy semantycznie mit wielkości państwa polsko-litewskiego), którego zmienne losy ukazuje w artykule poświęconym jego dwudziestowiecznej konstrukcji i dekonstrukcji Robert Traba ${ }^{4}$. Badacz, koncentrując się na konkretnych wydarzeniach związanych z kultywowaniem pamięci o Grunwaldzie, zaznacza jednak znamiennie, że nie chodzi mu „o samą obrzędowość grunwaldzką, [...] lecz o mechanizm kreowania narodowego mitu, pobudzanie bądź schładzanie narodowych emocji poprzez umiejętne posługiwanie się »słowem " w debatach pu-

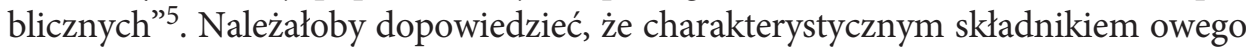
mechanizmu kreacyjnego jest wiara, że poszczególne wysłowienia mitu grunwaldz-

3 C. Lévi-Strauss, Antropologia strukturalna, przeł. K. Pomian, Warszawa 2009, s. 211.

${ }^{4}$ R. Traba, „Konstrukcja i proces dekonstrukcji narodowego mitu: rozważania na podstawie analizy semantycznej polskich obchodów rocznic grunwaldzkich w XX wieku", Komunikaty Mazursko-Warmińskie 1999, nr 4.

${ }^{5}$ Ibidem, s. 515. 
kiego spaja jakaś istotna treść, że odwołuje się on do pewnych ukrytych stanów rzeczy (narodowe emocje). Fakt, że w ostatnich latach mit ten — tak jak wiele innych mitów narodowych - uległ pewnego rodzaju emocjonalnej i ideologicznej degradacji, z jednej strony zdaje się obnażać jego przygodność (a więc pośrednio negować samą „mityczność" mitu), z drugiej zaś zachęca, by zadać pytanie, czy wiara, o jakiej była mowa przed chwilą, nie jest - jeśli nie w tym, to przynajmniej w niektórych innych przypadkach — tożsama z „treścią”. Wraz z zanikiem wiary znikałby też mit, poświadczając tym samym swoją fantazmatyczną naturę. Traba ów proces degradacji wiąże, zapewne słusznie, z postępującą demokratyzacją (w domyśle - pluralizacją) życia społecznego w Polsce. „Im bardziej — zauważa badacz — postępują procesy demokratyzacji i kształtowania się społeczeństwa obywatelskiego, tym bardziej tracą siłę czynniki mito- i kultotwórcze jako symbole polskiej jedności narodowej”6.

Cechą mitu, którą staram się tu uwypuklić jest jednak jego „obiektywność”, przez którą rozumiem - warto to zaakcentować ponownie — jego zakorzenienie w realnym porządku rzeczy: mit to przecież historia wykazująca moc trwania przewyższająca jego językowe „uwarunkowania”, ekscerpcja pewnego zasobu doświadczeń społecznych, a sięgając do fundamentów - symboliczny analogon struktur ontologicznych. Skoro tak, nie powinna nas zwieść nietrwałość jego określonych przejawów, które w świetle powyższych konstatacji mielibyśmy prawo uważać za epifenomenalne. Słabnięcie czynników mitotwórczych, o którym pisze Traba, można by — pozostając w dukcie tego rozumowania - uznać za sygnał przemieszczania się tkwiących w nich wcześniej mocy do innych niż oficjalne i uświęcone tradycją obszarów społecznego zaangażowania, na przykład do poszczególnych sektorów kultury masowej, takich jak sport, kino, estrada czy literatura popularna. Przeto znaczenie i rola mitu nie wyczerpują się w jego funkcjach estetyczno-perswazyjnych. Trudno zgodzić się z Karen Armstrong, gdy pisze, że mit jest „prawdziwy, bo jest skuteczny, a nie dlatego, że daje nam informacje o faktach"7.

Wymownym przykładem trwałości struktur mitycznych i ich zakorzenienia w realnobytowym wymiarze wspólnotowej egzystencji mogą być rosyjskie konstanty kulturowe, rozpoznawalne w nader zmiennych i heterogenicznych formach tekstualności. Związki realnego (olbrzymia przestrzeń kraju o trudnych w istocie do określenia granicach) i symbolicznego (mistycyzacja obrazu Rosji prowadząca w politycznej praxis do jego swoistego „rozpłynięcia się”, co znajduje wyraz między innymi w nieistnieniu potrzeby wyodrębnienia bytu o nazwie Republika Rosyjska ${ }^{8}$ ) wydają się tu bezdyskusyjne; dość przywołać słynne Tiutczewowskie frazy o Rosji, której nie da się ogarnąć rozumem, i o cesarstwie, któremu nie sposób wytyczyć granic ${ }^{9}$.

${ }^{6}$ Ibidem, s. 525.

7 K. Armstrong, Krótka historia mitu, przeł. I. Kania, Kraków 2005, s. 13.

8 Ani w ramach Rosyjskiej Radzieckiej Federacyjnej Republiki Socjalistycznej, ani we współczesnej Federacji Rosyjskiej nie powołano do życia bytu, który w znaczeniu prawno-politycznym można by utożsamiać z Rosją jako taką.

9 Odnośne fragmenty słynnych wierszy Fiodora Tiutczewa wyglądają następująco: „Умом Россию не понять/ Аршином общим не измерить", Умом Россию не понять, http://ruthenia.ru/tiut- 
W wypadku polskiego syndromu imperialnego ontologiczne odniesienia mitu, podobnie zresztą jak sam mit, jawią się jako mniej przejrzyste i znacznie trudniejsze do klarownego zwerbalizowania. Trudności nastręcza już samo określenie jego realnobytowego desygnatu. Można je sprowadzić do prostego pytania: czy Polska była kiedykolwiek imperium? Próżno jednak byłoby szukać jednolitego w tej sprawie stanowiska historyków. Gdy mowa o okresach widocznego wzrostu znaczenia państwa polskiego (lub przynajmniej wzrostu ambicji tegoż państwa w dziedzinie polityki międzynarodowej), zdecydowanie częściej i dobitniej artykułowane jest określenie „mocarstwo" (I Rzeczpospolita), niekiedy z nieco deprecjonującym kwalifikatorem „regionalne”, lub „polityka mocarstwowa” (II Rzeczpospolita). Tymczasem, jak słusznie zauważa Piotr Kraszewski, „w języku potocznym »imperium« znaczy tyle samo co mocarstwo - państwo rozległe terytorialnie, dominujące nad swoimi bliższymi i dalszymi sąsiadami, uprawiające politykę ekspansjonistyczną, często też posiadające zamorskie kolonie" ${ }^{\prime 10}$. Nie wdając się w szczegółowe rozróżnienia terminologiczne, odnotujmy kulturowo-ideologiczny wymiar funkcjonowania państw o charakterystyce imperialnej, powiązany częstokroć z bardzo szerokim, „światowym" wymiarem ich oddziaływania. W świetle tego stwierdzenia Rzeczpospolita byłaby co najwyżej organizmem o pewnych cechach imperialnych, a to ze względu na możliwe do zidentyfikowania komponenty kulturowo-ideologicznego kształtowania i uzasadniania przez nią własnej wyróżnionej pozycji w otoczeniu międzynarodowym (sarmatyzm). W świetle tego rodzaju dystynkcji dotyczących realnego statusu wyłania się pytanie o to, jak polskie samopostrzeganie prezentuje się na skali wyznaczonej relacjami centro-peryferyjnymi. Czy mamy tu do czynienia z przejawami stabilnego, sekularnego trwania, czy też raczej ewolucji, a może wręcz nieciągłości? Utarło się przekonanie, że kulturę staropolską cechowało niezmącone, graniczące z samouwielbieniem poczucie pewności siebie (symbolizowane Rejowym „Polacy nie gęsi”), natomiast polską świadomość dziewiętnasto- i dwudziestowieczną miałoby wyróżniać resentymentowe, a więc utajone i wypierane, kultywowanie własnej niepełnowartosciowości. Czy jednak w istocie nastąpił tu przełom na poziomie myślenia mitycznego? Czy łatwo i szybko następujące restytucje mocarstwowych aspiracji (polityka sanacji, a później Gierka, reaktywacja koncepcji Międzymorza w czasach rządów PiS) nie przemawiałyby jednak za ciągłością?

Są jednak i inne pytania, na które odpowiedź wymagałaby aktywizacji wielorakich kompetencji badawczych. Czy żywotność, jaką wykazują się w polskim dyskursie tożsamościowym protoimperialne „gestalty pojęciowe”, takie jak na przykład polskie wybraństwo narodowe, zakorzenione w sarmackim micie etnogenetycznym, jest dzisiaj (a zarazem od dłuższego już czasu) tylko wyrazem dziewiętnasto- i dwudzie-

cheviana/stihi/bp/281.html (dostęp: 6.09.2018); „Москва, и град Петров, и Константинов град —/ Вот царства русского заветные столицы.../Но где предел ему? и где его границы -/На север, на восток, на юг и на закат?", Русская география, http://ruthenia.ru/tiutcheviana/stihi/bp/139.html (dostęp: 6.09.2018)

${ }^{10}$ P. Kraszewski, „Wstęp”, [w:] Cywilizacja Rosji imperialnej, red. P. Kraszewski, Poznań 2002, s. 8. 
stowiecznej nostalgii za utraconym statusem czy może odsłania bardziej zasadniczy problem poczucia niedoszacowania potencjału narodowego? Może przeświadczenie o polskiej wyjątkowości (wielkości) owocujące konkretnymi mitami, takimi jak antemurale christianitatis ( $w$ jego rozmaitych wcieleniach, od piętnastowiecznych konceptów dyplomatycznych do dwudziestowiecznej propagandy antybolszewickiej), wyszydzane po wielekroć przez demistyfikatorów tego rodzaju uroszczeń, nie znalazło dotąd tylko odpowiedniego (czytaj: skutecznego w wymiarze perswazyjności) języka dla uzasadnienia swoich racji? Może za pozorami tromtadracji kryje się, na przykład, żelazna logika myśli, określona przez takie czynniki jak potencjał rozwojowy czy geopolityczne umiejscowienie? Janusz Tazbir waży mit Przedmurza na szali cywilizacyjnych zasług, dostrzegając konsolacyjną rolę, jaką odgrywa on w świadomości narodów historycznie „niedowartościowanych” (zbliżenie do kategorii postkolonialnych jest tutaj aż nadto oczywiste). Byłby więc w tym ujęciu mit Przedmurza kompensacją niewykorzystanych szans i cywilizacyjnej marginalności ${ }^{11}$.

Oczywiście myślenie ukierunkowane na poszukiwanie dowodów „realności” mitu politycznego/narodowego zawsze znajdzie oparcie w tych czy innych faktach społecznych. Między mitem a owymi faktami istnieje jednak jeszcze strefa mediumiczna, którą wypełniają potrzeby/interesy określonej grupy społecznej. Na analitycznie najłatwiej uchwytnym poziomie mit polityczny/narodowy jest realny $\mathrm{w}$ tej mierze, w jakiej koresponduje z powołującymi go do życia potrzebami/interesami. Czy oznacza to jednak, że istnieją również mity pozbawione takiego związku, mity przeto „nierealne”? Otóż wydaje się, że „aberracyjność” mitów, którym nie potrafimy przypisać racjonalnej motywacji, jest jedynie pozorna. Fundamentalny poziom wytwarzania realności mitu pozwala się utożsamić z możliwie najszerszym wymiarem ontologii życia zbiorowego: przestrzenią (wielkość tejże, jej lokalizacją itp.), czasem (jako wartością utylitarną, swego rodzaju dobrem społecznym, współokreślającym efektywność zbiorowych działań), szeroko rozumianymi zasobami materialnymi pozostającymi w dyspozycji wspólnoty, jej potencjałem demograficznym itp. Dekonstrukcja mitu nie powinna poprzestawać na identyfikacji i rozbiórce takich elementów, jak jego historyczny desygnat (określona formacja społeczno-polityczna osadzona w określonym okresie historycznym) ${ }^{12}$, twórcy, kodyfikatorzy i translatorzy jego tekstualnych upostaciowań czy dominujące w ramach tych ostatnich modele

11 „Tak więc, mimo odbywającego się na naszych oczach krachu europocentryzmu, tytułem do szczególnej chwały pozostaje obrona kultury, powstałej właśnie na naszym kontynencie. Nadal są w niej dostrzegalne istotne wartości. Narody, które nie mogą czerpać satysfakcji z tego, iż stanowiły kolebkę wielkich prądów cywilizacji, osiągnięć w zakresie sztuki czy nauki na skalę europejską (jeżeli nie światową), starają się przynajmniej wykazać, iż bez orężnej osłony jaką świadczyli, europejska wspólnota kulturowa przestałaby po prostu w pewnym momencie istnieć. Antemurale jest przedstawiane jako jedno z ogniw tradycji, która do czegoś w końcu zobowiązuje”, J. Tazbir, „Najnowsze spory o polskie Przedmurze 1939-1992", Kwartalnik Historyczny 1993, nr 4, s. 261.

12 Dyskusja o imperializmie danego projektu politycznego zawsze dotyczy jakiegoś wycinka narodowej przeszłości. Imperializm in statu nascendi, żeby zostać w ogóle zauważony, musi mieć za sobą rację dostateczną w postaci gotowych opowieści, symboli itp.

Miscellanea Posttotalitariana Wratislaviensia 8, 2020

(C) for this edition by CNS 
figuratywności. Celem wyższego rzędu powinna być rekonstrukcja ontologicznych uwarunkowań postaw wspólnotowych i konfrontacja tych uwarunkowań z samoobrazem wspólnoty (poziom potrzeb/interesów), które to uwarunkowania i samowyobrażenia historia mityczna we właściwy sobie (i tylko sobie) sposób konotuje.

Z jakimi, na przykład, poziomami „urealniania” będziemy mieli do czynienia w przypadku mitu sarmackiego, posługującego się egzotycznym z dzisiejszego punktu widzenia sztafażem historycznym i nie mniej osobliwą logiką wspierającego go wywodu społeczno-politycznego? Stefan Zabłocki dostrzega w tym micie dwie funkcje, które możemy zapewne utożsamiać z głównymi motywami jego powstania (potrzebami/interesami społecznymi). Pierwsza z nich obliczona jest na użytek wewnętrzny i wiąże się z potrzebą integracji i konsolidacji narodu do niedawna jeszcze, $w$ dobie Piastów, rozbitego przez podziały dzielnicowe. Poświadcza ją między innymi Długoszowe „Sarmatae sive Poloni”, „tam Rutheni, quam Poloni Sarmatae nominantur”. Druga funkcja z kolei wiąże się z zagrożeniem zewnętrznym. „Oto teoria o wspólnym pochodzeniu mieszkańców świeżo zjednoczonego królestwa - zauważa Zabłocki - służyć mogła odparciu starej pretensji cesarstwa do zwierzchnictwa nad wszystkimi ludami chrześcijańskimi”13. Rozpoznanie Zabłockiego dotyczy niewątpliwie poziomu, który opatrzyłem hasłem potrzeb/interesów; w danym przypadku wspólnym mianownikiem będzie tu zapewne potrzeba bezpieczeństwa i konsolidacji (nie zaś ekspansji). Dyskurs sarmacki w tej fazie swojego rozwoju zdaje się jednak komunikować więcej: zrozumienie ograniczeń, jakie wynikają z istniejących podziałów wewnętrznych oraz z niedostatku potencji do ich przezwyciężenia (stąd między innymi dążenie do inkluzji elementu ruskiego). Zwykle interpretacje roli sarmatyzmu odwołują się do szlacheckiej amour-propre oraz do związanej z nią sfery obyczajowości i ceremoniału. Motywacja pragmatyczna, jeśli nawet jest dostrzegana, ulega pewnej symplifikacji, jak na przykład wówczas gdy próbuje się sarmatyzm przedstawiać jako siłę integrującą wieloetniczne środowisko szlacheckie (tak jakby kwestia integracji pojawiła się na końcu pewnego procesu społecznego jako jego logiczna implikacja, nie zaś na samym początku — jako przesłanka działań zorientowanych na konsolidację państwa) ${ }^{14}$. Rozpoznania tego rodzaju muszą, rzecz jasna, jawić się jako dyskusyjne: nie dotyczą wszak wymiaru operacyjnego (zdarzenia, ludzie, procesy odzwierciedlane w poszczególnych tekstach), lecz samych fundamentów wspólnotowej ontologii („styk” mitu i rzeczywistości). To, jak wspól-

13 S. Zabłocki, „Paradoksy sarmatyzmu”, Teksty: teoria literatury, krytyka, interpretacja 1975, nr 3, s. 125.

14 „Dwie były przyczyny tak szybkiego i łatwego przyjęcia u nas mitu sarmackiego (podważanego dopiero w dobie Oświecenia, a ostatecznie obalonego przez Wawrzyńca Surowieckiego i Lelewela u progu romantyzmu). Po pierwsze dodawał on młodemu państwu splendoru poprzez dostojny, antyczny rodowód (co było w tym czasie w całej Europie poszukiwane i praktykowane). Po drugie - i to chyba istotniejsza przyczyna - pozwalał objąć jednym pojęciem quasi-narodowym rozliczne nacje, jakie weszły w XVI wieku w skład Rzeczypospolitej Obojga Narodów”, J. Maciejewski, „Sarmatyzm jako formacja kulturowa (Geneza i główne cechy wyodrębniające)", Teksty: teoria literatury, krytyka, interpretacja 1974, nr 4, s. 14-15. 
nota odnosi się do takich kwestii jak jej położenie geograficzne, wielkość i zasoby, którymi dysponuje, jej sąsiedzi czy też miejsce w ramach większych wspólnot (na przykład chrześcijaństwo, Europa, Słowiańszczyzna itp.), kodowane jest głęboko, na poziomie archetypicznej generatywności i manifestuje się jako zespół mniej czy bardziej trwałych dyspozycji mentalnych. Rozpoznanie przeto, o jakim mowa, nie wyczerpuje się w porządku czynności intelektualnych, uruchamia również - o ile dotyczy podmiotu zaangażowanego w życie danej wspólnoty - mechanizmy psychologiczne (możemy wówczas mówić o pewnych jego walorach terapeutycznych).

W podjętych rozważaniach nie chodzi wszelako o prezentację katalogu polskich mitów i udowadnianie za ich pomocą istnienia stałych determinant przesądzających kwestię polskiej imperialności. Pomijając oczywisty fakt zmienności historycznych uwarunkowań, wymagałoby to przywołania rozbudowanego aparatu krytycznego i odpowiedniej dla niego podstawy źródłowej, na co nie ma miejsca w porządku niniejszych rozważań. Chodzi przede wszystkim o zasygnalizowanie potrzeby modernizacji słownika, którego używa się w dyskusji nad polskim imperializmem. Słownik dotychczasowy, którego reguły określała z jednej strony strategia szyderstwa, z drugiej zaś mocarstwowa tromtadracja, odwzorowuje w zasadzie klisze poznawcze obciążające polskie samopostrzeganie. Fatalną okolicznością jest również to, że refleksję nad polskim imperializmem podejmowano dotąd w łonie wąskich, specjalistycznych gremiów. Stawka w tej dyskusji jest jednak, jak sądzę, dość wysoka. Jest nią pozyskanie stronników do realistycznej oceny miejsca i roli Polski w świecie, zarówno minionym, historycznym, jak współczesnym, wykazującym ambicje przezwyciężania historyczności i definiowania się w kategoriach uniwersalności i globalności. Przy czym, co znamienne, realizm nie polegałby tu na dekonstruowaniu polskich mitów i obnażaniu w ten sposób ich dysfunkcjonalności, lecz na traktowaniu ich jako tekstów kultury, u podstaw których dokonuje się ważna transformacja realnego w symboliczne.

Zgodnie z tym, co zostało dotąd powiedziane, pierwszym krokiem do urealnienia hermeneutyki mitograficznej jest oczyszczenie mitu z akcydentalno-epifenomenalnych nawarstwień i przyjrzenie się temu, czym on jest w wymiarze mythos. A sięgając głębiej, do sfery jego związków z rzeczywistością — jaka jest jego podstawa „źródłowa” (w sensie realnobytowych uwarunkowań). Trzeba przy tym zauważyć, że rekonstruowanie przesłania mitycznego, będące realizacją frapującego zadania intelektualnego, może też niekiedy ewokować doniosłe trudności natury etycznej. Nie wystarcza bowiem samo sięgnięcie do podstawy ontologicznej mitu; zadanie nie wyczerpuje się przecież w ramach czystej deskrypcji, lecz oparte jest, przynajmniej w pewnej mierze, na hermeneutyce rozumienia (rozumiejąc sytuację, w jakiej znajduje się dana zbiorowość i jaka określa jej samopostrzeganie, nieuchronnie zajmuję stanowisko wobec formułowanych przez nią racji: aprobuję je, potępiam lub dystansuję się od nich; wybór neutralności jest w danym przypadku również określonym wyborem moralnym). W przypadku organizmów o jawnie imperialnej charakterystyce, przesłanie mityczne jest $\mathrm{z}$ reguły proste: chodzi o uzasadnienie imperialnych 
działań, względnie złagodzenie obrazu związanej z nimi nieuchronnie przemocy. Wybór opcji moralnej powinien być wówczas dla obserwatora zewnętrznego łatwy; takim też jest dla badacza motywowanego etyką postkolonialną. Kłopot pojawia się wówczas, gdy rozpoznajemy casus organizmu o problematycznym statusie imperialnym. W tym kontekście należałoby mówić zwłaszcza o imperializmach przegranych, imperializmach utopijnych bądź imperializmach-projektach niedokończonych. W interpretacjach osobliwego statusu tak rozumianych imperializmów możemy natrafić na wiele czynników utrudniających lekturę podstawowego przesłania fundujących je mitologii. Dzieje się tak za sprawą odległości, która występuje tutaj między realnym położeniem a uobecnionym w micie samopostrzeganiem i która może być duża. Imperializmy nieklasyczne (tak je umownie nazwijmy) są na ogół kłopotliwym odstępstwem od imperializmów klasycznych, którymi zajmuje się teoria postkolonialna i postrzegane są jako rezultaty określonych „niedostosowań” do rzeczywistości. Jednak stwierdzenie, że nie będąc imperializmami zwycięskimi, „markowymi”, nie wykazują się — również w warstwie narracyjno-symbolicznej — właściwą tamtym adaequatio intellectus et rei, trąciłoby upraszczającą stereotypizacją.

Ostatnia kwestia naprowadza nas na ważne pytanie, być może najważniejsze z serii dotąd zadanych: $\mathrm{z}$ czego właściwie wynikają problemy z polskim imperializmem? Dlaczego nie utrwala się nawyk mówienia i pisania o nim w trybie jednoznacznych kategoryzacji rzeczowych, terminologicznych i moralnych? Czy wyłącznym powodem jest oddalenie w czasie oraz brak samopotwierdzenia w postaci trwałych i spektakularnych efektów (kulturowych, cywilizacyjnych) jego działań? A może problematyczność wynika po prostu z wewnętrznych uwarunkowań podmiotu, który uchodzi w powszechnej opinii za jego nosiciela - Rzeczypospolitej szlacheckiej?

Wyjdźmy od konstatacji pewnej oczywistej, lecz znaczącej zależności. Zarówno dla historyków zajmujących się „rzeczową” stroną zagadnienia, jak dla kulturalistów skoncentrowanych na jego stronie „wyobrażonej”, głównym odniesieniem - w tym drugim przypadku nie zawsze co prawda wprost - pozostaje państwo utworzone na podstawie unii polsko-litewskich, którego budowa, rozkwit i upadek zawiera się między schyłkiem XIV a końcem XVIII wieku. Gdyby takie państwo nie zaistniało, a nadto gdyby nie wykazywało się określonym zestawem cech i działań, cały późniejszy dyskurs osnuty wokół - rzeczywistego bądź domniemanego — polskiego imperializmu oraz jego rozlicznych implikacji, nie miałby racjonalnego uzasadnienia. Uwaga ta przypomina jedynie o fundamentalnym osadzeniu zagadnienia polskiego imperializmu w określonym obszarze narodowej historii, nie przesądzając wcale rzecz jasna kwestii metodologicznych, takich jak na przykład waga, jaką dla rzeczonego dyskursu winny mieć źródła historyczne. Uznanie dla symboliczno-narracyjnej tradycji fundującej obraz polskiej mocarstwowości pomaga uprawdopodobnić istnienie realnego, historycznego desygnatu tej mocarstwowości jedynie w wymiarze psychologiczno-kulturowym.

Nie powinno nam natomiast przesłaniać faktu, że przypisywaniu Polsce i jej kulturze statusu imperialnego nie towarzyszy właściwie nigdy, wyjąwszy aberracje 
myślenia sarmackiego, przeświadczenie o determinacji tego statusu przez czynniki obiektywne. Możemy oczywiście skwitować problem stwierdzeniem, że niedostrzeganie takich determinant wcale nie musi świadczyć o ich braku, i zwekslować go na tradycyjnie rozumianą historiografię. Nie od dziś jednak spory historyków wokół takich kwestii jak przyczyny wzrostu i upadku I Rzeczypospolitej, nie mówiąc o ocenie tych zjawisk, należą — w praktyce - do rzędu niekończących się debat. Argumentacja posługująca się kategoriami sił i potencjałów, uruchamiana notorycznie przez dwudziestowieczną geopolitykę, niewiele, jak się zdaje, może nam tu pomóc. Aplikowanie współczesnych form konceptualizacji do odległych w czasie zjawisk społecznych (przy nieuniknionych lukach i defektach materiału źródłowego) jest, jak wiadomo, zawsze poznawczo ryzykowne, w odniesieniu zaś do rozpatrywanego zagadnienia występuje wiele dodatkowych trudności. Jedna $\mathrm{z}$ nich wiąże się z samą kategorią imperialności stosowaną do państwa, które z całą pewnością nie było klasycznym imperium. Możliwe zaś porównania do organizmów o zbliżonej strukturze społecznej, takich jak szesnastowieczna Hiszpania, czy do potęg o podobnie spektakularnym wzroście znaczenia międzynarodowego, jak siedemnastowieczna Holandia, muszą zawodzić ze względu na zbyt dużą liczbę zmiennych różnicujących (na przykład morska orientacja ekspansji hiszpańskiej w przeciwieństwie do lądowej ekspansji Rzeczypospolitej czy protokapitalistyczny rozwój Zjednoczonych Prowincji bardzo wyraźnie sprzeczny z refeudalizacją zachodzącą na ziemiach polskich). Wiemy też, jak ogromną, prawdopodobnie decydującą, rolę w wyodrębnianiu się odmienności rozwojowych Rzeczypospolitej w stosunku do innych mocarstw europejskich XV-XVII wieku odegrały czynniki natury jakościowej (ideologiczne, prawne, instytucjonalne, w zakresie kapitału społecznego itp.). Zgodnie z ustaleniami Andrzeja Wyczańskiego różnice potencjałów, jakie zachodziły w XVI wieku między Rzeczypospolitą szlachecką a znaczącymi państwami Zachodu, nie były tak istotne, by zadowalająco tłumaczyć osobliwość losów tej pierwszej w dwóch kolejnych stuleciach ${ }^{15}$.

Analizę obliczoną na poszukiwanie twardych czynników kształtowania potęgi politycznej dawnej Rzeczypospolitej trudno właściwie zakotwiczyć w jakimś stabilnym zbiorze danych, takim jak - na przykład — infrastruktura, transportowa i społeczna, sprzyjająca rozwojowi handlu międzynarodowego, jak zalety położenia geograficznego czy wreszcie jak zasoby demograficzne lub naturalne, sprzyjające ekspansji naturalnej bądź militarnej itp. Oczywiście niektóre z tych elementów odegrały określoną rolę jako czynniki wzrostu Polski szlacheckiej. Przeważający pogląd każe wyróżnić wśród nich rolę handlu zbożem, jakkolwiek trudno sobie wyobrazić, by tak dynamiczna i złożona forma działalności jak handel mogła być strukturalnym

15 „Wszystkie nasze wywody na temat Polski wieku XVI wskazywały, że przy całej gamie szczegółowych różnic i odmienności Polska tego okresu mieściła się wraz ze swą gospodarką, strukturą społeczną, państwowością i kulturą w ramach zjawisk występujących w innych krajach europejskich, w ramach jakiejś ogólniejszej prawidłowości procesu historycznego. Należy podkreślić, że w XVI stuleciu te polskie odmienności były niezbyt wielkie i chyba wyraźnie mniejsze niż w ciągu następnego półtora wieku naszych dziejów”, A. Wyczański, Polska w Europie XVI stulecia, Poznań 1999. 
czynnikiem rozwojowym w państwie o słabo rozwiniętej sieci miejskiej i niemal pozbawionym floty.

Można wręcz odnieść wrażenie, że w przypadku Polski i Litwy mamy do czynienia z czymś w rodzaju mocarstwowości przygodnej i efemerycznej, kultywowanej niejako ponad stan. Wrażenie ogólnej słabości pogłębia jeszcze jej etos pośmiertny, oparty na niemal wyłącznie symbolicznej eksploatacji dziedzictwa I Rzeczypospolitej. Dziedzictwa, co znamienne, nielegitymizowanego jako pozytywne i nieuznawanego za własne/wspólne przez jego niepolskich beneficjentów (Litwini, Białorusini, Ukraińcy). Symboliczność tę podkreśla fakt, że projekty wyrosłe wokół odradzającej się na początku XX wieku państwowości polskiej, takie jak koncepcja federacyjna Piłsudskiego czy prometeizm, a związane genealogicznie z etosem politycznym I Rzeczypospolitej, wykazały się fundamentalną nieskutecznością ${ }^{16}$.

Takie podejście wiąże się z krytycznym nastawieniem do dziedzictwa sarmackiego i w praktyce oznacza jego dezawuację. Sprowadza się ono do poglądu, że polska przygoda $z$ imperializmem, nawet jeśli uznać ją za coś więcej niż sen na jawie, była jedynie efektem splotu specjalnych okoliczności, których ustąpienie przekreśliło - raz na zawsze - możliwość jej powtórzenia. Istnieją jednak wykładnie przychylne rodzimemu dziedzictwu imperialnemu, widoczne zwłaszcza w środowiskach intelektualnych kojarzonych ze współczesną polską prawicą ${ }^{17}$.

Nie wchodząc w szczegóły sporów rozpiętych między afirmacją i dezawuacją, trzeba jednak sprawiedliwie przyznać, że na tle imperializmów ościennych, niemieckiego i rosyjskiego, którym przypisywana jest nieomal metafizyczna zdolność do samoregeneracji, polski, zamknięty w określonych ramach czasowych, prezentowałby się nader skromnie. Dlatego wizja polskiego imperializmu jako przedsięwzięcia jednorazowego, a nawet jako produktu ubocznego działań obliczonych na cele zgoła inne niż budowanie potężnego państwa (sprowadzenie Krzyżaków, które stworzyło potrzebę aliansu z Litwą itp.), ma swoją niezaprzeczalną siłę sugestywną.

Tendencjom dekonstrukcyjnym przeciwstawia się skłonność do remityzacji, nierzadko pobłażliwa wobec zachodzących na tym tle wynaturzeń. Należy zauważyć, że w dzisiejszych czasach imperializmy o wyczerpanych bądź ograniczonych potencjałach rozwojowych (rosyjski w wersji postsowieckiej), imperializmy będące definitywnie przegranymi lub niedokończonymi projektami (tu przykładem mógłby być

16 Nie możemy przy tym zapominać o ogromnej atrakcyjności, jaką ustrój państwowy I Rzeczypospolitej wykazywał się w oczach zamieszkującego ją narodu szlacheckiego. W ustroju tym, jak zauważa Edward Opaliński, nastąpiło „pełne utożsamienie się szlacheckich obywateli z systemem parlamentarnym, którego istotę stanowili jako posłowie, i pełne utożsamienie się obywateli z państwem, które nie tylko zbudowali w przeszłości, ale tworzyli i stanowili obecnie", idem, Sejm srebrnego wieku 1587-1652, Warszawa 2001, s. 193.

17 „W marzeniach o terytoriach zamorskich widać też awanturniczą żyłkę, przedsiębiorczość, śmiałość i gotowość do ryzyka, które przez wieki cechowały naszych przodków. To przecież dzięki tym przymiotom Polska z niewielkiego kraju Europy Środkowej przeistoczyła się w czołowe mocarstwo Europy Wschodniej. To dzięki nim wypłynęliśmy na szerokie wody”, P. Zychowicz, „Duch przygody”, Historia Do Rzeczy 2015, nr 7. 
zapewne polski), a także imperializmy kojarzone z odległą, na wpół już legendarną, przeszłością danej zbiorowości (węgierski), są wyraźnie bardziej podatne na retrospektywne mityzacje niż imperializmy zwycięskie, o „dobrej” imperialnej marce. Te ostatnie, przeciwnie, wykazują otwartość na krytyczne redefinicje ich historycznych ról, co czyni je naturalnymi „sojusznikami” studiów postkolonialnych. Blask minionej chwały zdaje się niewygasającym, lecz nierzadko i zwodniczym, źródłem inspiracji dyskursów tożsamościowych narodów o zakłóconej charakterystyce imperialnej. Przy czym trudno tu o jednoznaczność uogólnień. Niektóre z takich dyskursów zdają się opierać na samoreprodukujących się mechanizmach tekstualnych, inne zaś próbują nawiązywać do realnych uzasadnień swoich mitologii.

Przeświadczenie, że tylko w gestii historyków leży kompleksowa ocena dorobku i znaczenia Rzeczypospolitej szlacheckiej, nie sprzyja dziełu rekontekstualizacji polskiego dyskursu tożsamościowego. Rekontekstualizacja taka zaś wydaje się uzasadniona w związku z coraz liczniejszymi interpelacjami, jakim poddawane są dziś przez kulturalistów tradycyjne (auto)narracje tożsamościowe. Interpelacje takie dotyczą zasadniczo, zgodnie z kulturalistyczną metodologią, spójności i wiarygodności tradycyjnych wspólnotowych samoobrazów. Do grona najbardziej dociekliwych interpelantów należą niewątpliwie badacze postkolonialni. Postcolonial studies, rekomendowane przeze mnie do roli czynnika nie tyle dekonstruującego, ile integrującego rozproszone w świecie akademickim kompetencje badawcze i formy krytycznej refleksji, które w innym wypadku prawdopodobnie nie weszłyby w owocne alianse, wymagają wszelako respektowania pewnego etycznego minimum: odróżniania podmiotu i przedmiotu dominacji, przydawania im odpowiednich kwalifikatorów moralnych. Sprawia to, że refleksyjność postkolonialna naznaczona jest nieuchronnie ideologicznością. Nie inaczej jest zresztą w wypadku polskiego dziedzictwa imperialnego jako przedmiotu badań postkolonialnych. Nie da się ukryć, że ciąży na nim — przynajmniej potencjalnie - sprzeczność, jaka zachodzi między afirmacją domniemanej imperialnej przeszłości jako źródłem kompensacji narodowych słabości i porażek a deprywacją, której ryzyko występuje zawsze w związku z możliwością niekorzystnej z punktu widzenia utrwalonych wyobrażeń konfrontacją mitu z rzeczywistością. Pokrywa się to mniej więcej z postkolonialną opozycją binarną: hegemon-subaltern ${ }^{18}$. Trzeba pamiętać, że polska perspektywa jest tu zasadniczo różna od tej, w jakiej umieszczają owo dziedzictwo niektóre narody ościenne, zwłaszcza litewski i ukraiński.

Dystans, a nierzadko nawet jawna niechęć, z jaką na gruncie polskiej nauki historycznej spotykają się studia postkolonialne, sprawia, że próby łączenia w jedną całość czynnika „substancjalnie” historycznego z kulturalistycznym traktowane są

18 „W naszej świadomości narodowej wyróżnić można dwa kompleksy kolonialne: 1) nostalgia za kresami, 2) upokorzenia okresu rozbiorów, okupacji hitlerowskiej i sowieckiej. W rezultacie, polski czytelnik znajduje się dziś w epistemologicznie wyjątkowo korzystnej sytuacji, jest bowiem w stanie odnieść do swojego dziedzictwa kulturowego zarówno mentalność ciemiężyciela, jak i ciemiężonego [...]", K. Kowalczyk-Twarowski, „Imperialne przestworza, spolegliwi tubylcy: Polska, Rosja, RPA”, ER(R)GO. Teoria - Literatura - Kultura 2004, nr 1, s. 174-175. 
- nie tylko zresztą, dodajmy, przez historyków - w najlepszym razie jako rodzaj interesującego wyzwania rzuconego tradycyjnie rozumianej naukowości. Niewątpliwie nie ma zatem w Polsce szerszego przyzwolenia (a jednocześnie pewnej tradycji intelektualnej) na rozprawianie się z wielkimi tematami tożsamościowymi, do jakich niewątpliwie należy rozpatrywane tu zagadnienie (post)imperialności, przy użyciu heterogenicznych słowników.

Pole dyskusji nad polską tożsamością w jej kontekście imperialno-kolonialnym określiły w ostatnich latach zwłaszcza dwie książki, z których szczególnie pierwsza może jawić się jako modelowe ucieleśnienie badawczej heterogeniczności (dość przywołać jej wielobiegunową inspirację metodologiczną: od marksizmu, przez szkołę Annales do psychoanalizy lacanowskiej): Fantomowe ciało króla. Peryferyjne zmagania $z$ nowoczesna formą ${ }^{19}$ Jana Sowy oraz Trójkąt ukraiński. Szlachta, carat i lud na Wolyniu, Podolu i Kijowszczyźnie 1793-1914 Daniela Beauvois, francuskiego historyka i slawisty. Ich sukces wydawniczy, wielorakie reakcje, które wywołały, możemy odbierać jako sygnał udanego włączenia wspomnianego kontekstu do współczesnej debaty tożsamościowej w Polsce, a jednocześnie jako rezultat nawarstwienia się pewnych niedoczytań i uproszczeń, jakie wydają się niekiedy charakteryzować polskie samopostrzeganie oraz polską percepcję miejsca i roli Polski $\mathrm{w}$ świecie ${ }^{20}$. Łączy obu autorów niewątpliwie to, że rozprawiają się z polskimi mitami narodowymi w sposób radykalny i, jeśli wolno tak powiedzieć, dogłębny, narzucając tym samym pewien styl krytycznego rozprawiania o polskości. Styl w obu przypadkach czerpiący wyraźnie z poetyki postkolonialnej ${ }^{21}$. Metoda Sowy wyka-

19 J. Sowa, Fantomowe ciało króla. Peryferyjne zmagania z nowoczesną formą, Kraków 2011.

20 „W mojej ocenie w dotychczasowym dorobku polskiej historiografii poświęconej Kresom Wschodnim nad obiektywnymi badaniami przeważają opracowania niezmiennie obciążone bezkrytycznym zachwytem generowanym przez polski mit Kresów, którego początek datowany jest już na pierwszą połowę XIX wieku”, B. Hud, Ukraińcy i Polacy na Naddnieprzu, Wołyniu i w Galicji Wschodniej w XIX i pierwszej połowie XX wieku. Zarys historii konfliktów społeczno-etnicznych, przeł. A. Korzeniowska-Bihun, M. Hud, Lwów-Warszawa 2013, s. 56.

21 „Każdy naród w tym okresie przełomu [rozpadu imperium sowieckiego - T.N.] winien zdać sobie jasno sprawę ze swej przeszłości. Zatem dla Polaków nadszedł bez wątpienia czas uznania »kolonialnego « charakteru ich obecności na Ukrainie, z której w końcu zostali wygnani. Możemy dyskutować i twierdzić, że bardzo dawne panowanie Polaków na prawym brzegu Dniepru — przez ponad cztery stulecia - miało raczej charakter feudalny, co potwierdzają rusińskie korzenie wielu znacznych rodów spolonizowanych od XVII wieku, lecz zarówno sposób traktowania miejscowej ludności, jak i typ gospodarki latyfundialnej, nastawionej przede wszystkim na eksport, przypomina nade wszystko system kolonialny właśnie”, D. Beauvois, Trójkąt ukraiński. Szlachta, carat i lud na Wołyniu, Podolu i Kijowszczyźnie 1793-1914, przeł. K. Rutkowski, Lublin 2016, s. 707.

„Ekspansja na wschód I Rzeczypospolitej była procesem porównywalnym pod wieloma względami z budową imperiów kolonialnych przez Hiszpanię, Francję i Anglię. Stanowiła zaplanowane i zorganizowane przedsięwzięcie. Dokonywała się przy użyciu środków militarnych, politycznych i cywilnych (napływ kolonizatorów). Miała swój sens i wymiar gospodarczy, stając się dla polskich i litewskich elit dwunarodowego państwa okazją do zbicia gigantycznych fortun. Spełniała podobną funkcję społeczną, wchłaniając nadwyżki ludności i dając najbardziej przedsiębiorczym jednostkom możliwość zdobycia pokaźnych fortun. Została obudowana teoretycznym dyskursem, którego celem było 
zuje się jeszcze jedną, wyróżniającą ją właściwością. Oto badacz ten konfrontuje się z najgłębszym, najbardziej fundamentalnym wymiarem mitu narodowego, który określiłem wcześniej mianem podstawy ontologicznej mitu. Sugestywność zaproponowanych przez Sowę i Beauvois wizji historii Polski jest tak duża, że można chyba dziś mówić o przyćmieniu przez nie konkurencyjnego w pewien sposób - na poziomie hermeneutycznym - dyskursu prawicowego (Jarosław Marek Rymkiewicz, Krzysztof Koehler czy Rafał Ziemkiewicz) ${ }^{22}$.

$\mathrm{Na}$ antypodach poglądów prezentowanych przez Sowę i Beauvois możemy umieścić stanowisko historyka Hieronima Grali, wyrażone dobitnie w polemicznym względem obu artykule pod tytułem Kolonializm alla polacca. Koronny argument przeciwko istnieniu polskiego imperializmu w dobie przedrozbiorowej Grala formułuje w formie zarzutu braku „należnego pietyzmu wobec materii źródłowej” wymierzonego w autorów takich jak właśnie Sowa i Beauvois, którzy budując swoje wizje historyczne odwołują się, jego zdaniem, do przykładów źle dobranych: już to anachronicznych, już to niereprezentatywnych, już to mieszających różne porządki narracyjne (na przykład literackie $z$ nieliterackimi) ${ }^{23}$.

Gdybyśmy jednak spór o polski imperializm/kolonializm sprowadzili do wymiaru metodologicznego, w którym osią dyskusji byłyby takie kwestie jak dobór i sposób potraktowania podstawy źródłowej itp., pozbawilibyśmy ów spór jego najistotniejszego składnika, jakim jest mit, a ściślej ewokacja pozatekstowych odnie-

wypracowanie metod najbardziej pożytecznego zagospodarowania nowych zdobyczy terytorialnych. Nawet pomysły, aby wykorzystać Kresy do pozbycia się jednostek dla społeczeństwa problematycznych, przypominają instytucje kolonii karnych utrzymywanych przez państwa Europy Zachodniej”, J. Sowa, op. cit., s. 332-333.

22 „Dziedzictwo sarmackie, dziedzictwo Polski szlacheckiej, dziedzictwo republikańskiego podejścia do przestrzeni publicznej, a także werbalna i realna tradycja wolnościowa (mówimy o wolności przed liberalizmem) to był polski kapitał. Rozumiem to w ten sposób, iż - mówiąc obrazowo - sporo odłożyliśmy na koncie i w czasach ciężkich właśnie tam sięgaliśmy, aby mieć siły do przetrwania", Prof. Krzysztof Koehler: Dziedzictwo sarmackie to polski kapitat, wywiad A. Talarowskiego z K. Koehlerem, https://www.teologiapolityczna.pl/krzysztof-koehler-dziedzictwo-sarmackie-to-polski-kapitalrozmowa- (dostęp: 6.09.2018).

23 „Nie jestem w stanie dostrzec podobieństw między kolonizacją Dzikich Pól a ekspansją moskiewską na Syberii czy ekspansją kolonialną hiszpańską, portugalską, angielską i holenderską. Osadnik nasz - zarówno kozacki, jak i magnacki - nie rugował wszak ludności rdzennej, nie podporządkowywał sobie "jasacznych ludów«, bo ich tam po prostu nie było! Odgrywał przy tym pozytywną rolę wobec terenów macierzystych, zabezpieczając ośrodki od niespodziewanych inkursji ordyńskich, przenikających uprzednio bez trudności przez niezamieszkane »ziemie niczyje«”, H. Grala, „Kolonializm alla polacca”, Polski Przegląd Dyplomatyczny 2017, nr 4, s. 99-100. „Rusini i Litwini zajmowali nierzadko pierwsze urzędy w państwie, sięgając regularnie po hetmańskie buławy i kanclerską pieczęć, zasiadali w senacie liczniej niż etniczni Polacy i stanowili potężną część reprezentacji sejmowej, ich język ojczysty zaś - inaczej niż w przypadku państw kolonialnych — zajmuje bardzo długo istotne miejsce wśród oficjalnych języków państwa, nie tylko na użytek administracji prowincjonalnej, ale także jako język urzędów centralnych i podstawowych zabytków prawodawstwa”, ibidem, s. 110. „Dyskutując o przydatności dyskursu postkolonialnego do badań nad dziejami Polski, powinniśmy dostrzec jego użyteczność w stosunku do innej epoki, porozbiorowej, i to zwłaszcza w Imperium Romanowów”. „Sytuacja kolonialna rzeczywiście stała się naszym udziałem, ale nie była to Rzeczpospolita przedrozbiorowa..., ibidem, s. 117. 
sień struktury mitycznej. Nie ma tu miejsca na prześledzenie debaty, jaka toczy się w Polsce od kilku lat wokół cytowanych prac Sowy i Beauvois, lecz widoczne w niej emocje zdają się świadczyć, że rzeczywisty jej przedmiot znajduje się na poziomie fundamentów (transformacji elementów ze sfery ontologicznej w mit), nie zaś operacyjnych niezgodności ${ }^{24}$.

Stawką jest tutaj bardziej ogólna wizja Polski i polskości, wykraczająca poza ramy odniesień stricte tekstualnych. Można powiedzieć, że idiosynkratyczność autorska, nieunikniona i stała zmienna procesu badawczego, wtapia się w danym przypadku w ów szczególny i niepowtarzalny horyzont idiosynkratyczności zbiorowych, na którego tle rozpoczyna się i kończy każda poważniejsza debata natury tożsamościowej. Nie sposób już dziś uciec od konfrontacji z pytaniami, jakie mogą i chcą zadawać nowoczesnym wspólnotom narodowym dociekliwe dyskursy kulturalistyczne, którym tradycyjne formy (auto)narracji i (auto)obrazów jawią się jako zaledwie cząstki większych całości.

Nie sposób jeszcze powiedzieć, czy polskie konfrontacje z przeszłością, jakich jesteśmy świadkami po roku 1989, doprowadzą do konsensusu aksjologicznego. Wątki imperialne i kolonialne, jakie się w ramach tych konfrontacji przewijają, stanowią zachętę do szerszej dyskusji na temat polskiej tożsamości, zwłaszcza zaś na temat fundujących ją mitów. Dyskurs postkolonialny, którego kategorie przywoływane są często w kontekście wspomnianych konfrontacji wydaje się dobrze odpowiadać celom różnych jej uczestników (odwołują się do nich zarówno „prawicowi”, jak „lewicowi” autorzy). Główną siłą przyciągającą tego dyskursu jest w danym przypadku fakt, iż - jak słusznie zauważa Dorota Kołodziejczyk — koncentruje się on na zagadnieniu tożsamości ${ }^{25}$. Trudno jednak uznać, by śmiałe i nonkonformistyczne interpelacje kulturalistów zainteresowanych polską historią i polską tożsamością, mogły stanowić jedyne lub bodaj najważniejsze narzędzie rekontekstualizacji narodowego habitusu. Potrzebne jest jeszcze dobre, rzeczowe rozpoznanie wielu obszarów polskiej świadomości i polskich praktyk społecznych w perspektywie ich ewolucji oraz wzajemnych związków. Przykładem takiego owocnego rozpoznania może być wydane niedawno trzytomowe studium nad dziejami polskiej inteligencji pod redakcją Jerzego Jedlickiego Dzieje inteligencji polskiej do roku $1918^{26}$.

${ }^{24}$ Oczywiście dyskusja na temat aplikowalności kategorii postkolonialnych do polskiej historii pozwala się dzisiaj, po upływie kilkunastu lat od pierwszych w tej mierze wystąpień, rozpisać na wiele głosów, wśród których znajdziemy również takie, które pochodzą z dyskursów obcych, zwłaszcza ukraińskiego (Jaroslav Hrycak, Bohdan Hud, Mykoła Riabczuk). Pojawiają się już nawet godne uwagi próby podsumowań i rewizji, by wspomnieć jedną z bardziej doniosłych, podjętą przez środowisko „Artes Liberales”. Perspektywy postkolonializmu w Polsce, Polska w perspektywie postkolonialnej, red. J. Kieniewicz, „Debaty Artes Liberales” 10, Warszawa 2016.

25 „Absolutną dominantą studiów postkolonialnych pozostaje wciąż tożsamość definiowana/opisywana w obrębie kilku nieesencjalistycznie traktowanych zmiennych, takich jak narodowość, etniczność, emigracyjność”, D. Kołodziejczyk, „Postkolonialny transfer na Europę Środkowo-Wschodnią”, Teksty Drugie: teoria literatury, krytyka, interpretacja 2010, nr 5, s. 27.

26 Por. M. Janowski, Narodziny inteligencji 1750-1831, Warszawa 2008; J. Jedlicki, Błędne koło 1832-1864, Warszawa 2008; M. Micińska, Inteligencja na rozdrożach 1864-1918, Warszawa 2008. Roz- 
Tożsamość wspólnoty wyznaczają pospołu czynniki dyskursywne i realnobytowe; obie te grupy możemy zresztą uznać za współwarunkujące się dialektycznie. Mit narodowy jawi się jako struktura scalająca je i transformująca na właściwych sobie prawach. Dzięki temu możemy traktować mit jako specyficzne narzędzie poznania; specyficzne nie tylko przez jego uwarunkowania językowo-gatunkowe, lecz także przez to, że występuje on na przecięciu realnego i wyobrażonego. Wskrzeszane nieświadomie bądź jawnie przywoływane we współczesnej kulturze polskiej (w nauce, literaturze, publicystyce, sztuce czy polityce) rodzime mity imperialne przynoszą z odległych epok treści, w których możemy rozpoznawać - na pewnym poziomie ogólności - dzisiejsze oblicza polskości i dzisiejsze jej odniesienia do świata zewnętrznego.

\section{Bibliografia}

Armstrong, Karen. 2005. Krótka historia mitu. Przeł. Ireneusz Kania. Kraków: Wydawnictwo Znak. Beauvois, Daniel. 2016. Trójkąt ukraiński. Szlachta, carat i lud na Wołyniu, Podolu i Kijowszczyźnie 1793-1914. Przeł. Krzysztof Rutkowski. Lublin: Wydawnictwo Uniwersytetu Marii Curie-Skłodowskiej.

Borkowski, Robert. 2014. Bezpieczeństwo strategiczne RP w kontekście amerykańskiej polityki wobec Europy Środkowej i konfliktu ukraińskiego. W: Dylematy polityki bezpieczeństwa Polski na początku drugiej dekady XXI wieku, red. Katarzyna Czornik, Miron Lakomy, 125-136. Katowice: Wydawnictwo Regionalnego Ośrodka Debaty Międzynarodowej w Katowicach.

Brzeziecki, Andrzej. 2017. Imperialne złudzenia Polski, https://www.reddit.com/r/Polska/comments/6cnj0j/imperialne_z\%C5\%82udzenia_polski/ (dostęp: 6.09.2018).

Grala, Hieronim. 2017. „Kolonializm alla polacca”, Polski Przeglad Dyplomatyczny 4.

Hud, Bohdan. 2013. Ukraińcy i Polacy na Naddnieprzu, Wołyniu i w Galicji Wschodniej w XIX i pierwszej połowie XX wieku. Zarys historii konfliktów społeczno-etnicznych. Przeł. Anna Korzeniowska-Bihun, Mariya Hud. Lwów-Warszawa: Pracownia Wydawnicza.

poznania, o jakich mowa, dotyczą nierzadko aspektów życia znanych wprawdzie, lecz nieuwypuklonych dostatecznie bądź nieumieszczonych w odpowiednim kontekście. Weźmy taki oto fragment opisujący mitologizowany powszechnie patriotyzm szlachty polskiej: „Zdecentralizowana struktura dawnej Rzeczypospolitej sprawiała, że życie publiczne toczyło się rytmem lokalnych sejmików raczej niż sejmu w Warszawie; a co za tym idzie, dla dużej części szlachty instytucje stanowego samorządu oraz stanowe przywileje — sławna »złota wolność« — ważniejsze były od nazwy państwa, jego herbu czy panującej dynastii. Osoba monarchy nie była (inaczej niż w dynastycznych monarchiach absolutnych) uważana za symbol państwa i suwerenności. Wierność szlachty wobec króla nigdy nie byłą bezwzględna, lecz uzależniano ją od przestrzegania przezeń szlacheckich przywilejów. Taki »kontraktowy« stosunek szlachty do monarchy mógł sprzyjać postawom powstańczym (w tradycji dawnych konfederacji), mógł też jednak ułatwić akceptację nowego porządku, o ile pozostawał cień nadziei, że nowy władca szanować będzie szlacheckie wolności. Sam fakt obcości kulturowo-językowej monarchy nie stanowił przeszkody [...]. Nie było więc chyba niczym moralnie dwuznacznym, gdy warszawskie elity żywiły nadzieję na podjęcie sprawy polskiej przez króla pruskiego Fryderyka Wilhelma III przy okazji jego wizyty w Warszawie w 1802 roku. Tadeusz Czacki, wkrótce twórca Gimnazjum Wołyńskiego w Krzemieńcu, wyrażał nadzieje, że Polacy zdołają wytłumaczyć królowi pruskiemu, iż w wyniku rozbiorów »jest panem wielkiego państwa, że przestał być margrabią brandenburskim «, a »monarchia pruska jest monarchią polskich krajów, w której urzędnicy są tylko Niemcami«", M. Janowski, op. cit., s. 112-113.

Miscellanea Posttotalitariana Wratislaviensia 8, 2020

(C) for this edition by CNS 
Janowski, Maciej. 2008. Narodziny inteligencji 1750-1831. Warszawa: Instytut Historii PAN: Wydawnictwo Neriton.

Jedlicki, Jerzy. 2008. Błędne koło 1832-1864. Warszawa: Instytut Historii PAN: Wydawnictwo Neriton.

Kieniewicz, Jan, red. 2016. Perspektywy postkolonializmu w Polsce, Polska w perspektywie postkolonialnej. „Debaty Artes Liberales”, t. 10. Warszawa: Wydział Artes Liberales Uniwersytetu Warszawskiego.

Koehler, Krzysztof, Adam Talarowski. 2017. Krzysztof Koehler: Dziedzictwo sarmackie to polski kapitat, wywiad A. Talarowskiego z K. Koehlerem, https://www.teologiapolityczna.pl/krzysztof-koehlerdziedzictwo-sarmackie-to-polski-kapital-rozmowa- (dostęp: 6.09.2018).

Kołodziejczyk, Dorota. 2010. „Postkolonialny transfer na Europę Środkowo-Wschodnią”, Teksty Drugie: teoria literatury, krytyka, interpretacja 5.

Kowalczyk-Twarowski, Krzysztof. 2004. „Imperialne przestworza, spolegliwi tubylcy: Polska, Rosja, RPA", ER(R)GO. Teoria - Literatura - Kultura 1.

Kraszewski, Piotr, red. 2002. Cywilizacja Rosji imperialnej. Poznań: Wydawnictwo Instytutu Wschodniego UAM.

Lévi-Strauss, Claude. 2009. Antropologia strukturalna. Przeł. Krzysztof Pomian. Warszawa: Wydawnictwo Aletheia.

Maciejewski, Janusz. 1974. „Sarmatyzm jako formacja kulturowa (Geneza i główne cechy wyodrębniające)", Teksty: teoria literatury, krytyka, interpretacja 4.

Micińska, Magdalena. 2008. Inteligencja na rozdrożach 1864-1918. Warszawa: Instytut Historii PAN: Wydawnictwo Neriton.

Sowa, Jan. 2011. Fantomowe ciało króla. Peryferyjne zmagania z nowoczesna formą. Kraków: Universitas.

Tazbir, Janusz. 1993. „Najnowsze spory o polskie Przedmurze 1939-1992”, Kwartalnik Historyczny 4, http://rcin.org.pl/Content/1894/WA303_3979_KH100-r1993-R100-nr4_KwartalnikHistoryczny\%2019\%20Tazbir.pdf (dostęp: 6.09.2018).

Tiutczew, Fiodor I. 1848/1849. Русская география, http://ruthenia.ru/tiutcheviana/stihi/bp/139.html (dostęp: 6.09.2018).

Tiutczew, Fiodor I. 1866. Умом Россию не понять, http://ruthenia.ru/tiutcheviana/stihi/bp/281.html (dostęp: 6.09.2018).

Traba, Robert. 1999. „Konstrukcja i proces dekonstrukcji narodowego mitu: rozważania na podstawie analizy semantycznej polskich obchodów rocznic grunwaldzkich w XX wieku", Komunikaty Mazursko-Warmińskie 4, http://bazhum.muzhp.pl/media//files/Komunikaty_Mazursko_Warminskie/ Komunikaty_Mazursko_Warminskie-r1999-t-n4/Komunikaty_Mazursko_Warminskie-r1999 -t-n4-s515-531/Komunikaty_Mazursko_Warminskie-r1999-t-n4-s515-531.pdf (dostęp: 6.09.2018).

Wyczański, Andrzej. 1999. Polska w Europie XVI stulecia. Poznań: Wydawnictwo Poznańskie.

Zabłocki, Stefan. 1975. „Paradoksy sarmatyzmu”, Teksty: teoria literatury, krytyka, interpretacja 3.

Przyjęto do druku/Accepted for publication: 31.04.2019

Miscellanea Posttotalitariana Wratislaviensia 8, 2020

(C) for this edition by CNS 